\title{
INVESTIGATION OF THE HERITABILITY OF PHENOTYPES OF FERTILITY AND MILK PERFORMANCE OF SIMMENTAL CATTLE BREED IN SERBIA
}

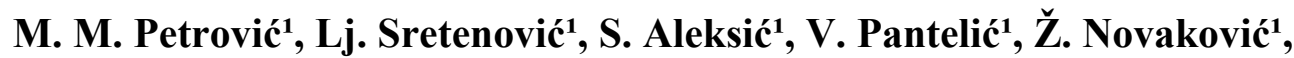 \\ P. Perišićć, M. D. Petrovićz
}

${ }^{1}$ Institute for Animal Husbandry, 11080, Belgrade-Zemun, Republic of Serbia

${ }^{2}$ Faculty of Agriculture, 11080, Belgrade-Zemun, Republic of Serbia

${ }^{3}$ Faculty of Agriculture, 32000, Čačak, Republic of Serbia

Corresponding author: milpet99@yahoo.com

Invited paper

Abstract: Results of the effect of direct and indirect selection of quantitative traits of fertility and milk performance of first calving cows of Simmental breed in Serbia are presented. Investigation of genetic parameters of heritability (additive genetic variance in total phenotypic variability of quantitative traits) and analysis of milk traits was done in four breeding regions and several tenths of farms where 3980 daughters of 32 sires were housed and reared. Results of analysis were obtained by application of mathematical-statistical data analysis, using mixed models (Harvey, 1990). Mathematical-statistical analysis of data was done using linear methods, i.e. method of least squares (LS method). Based on obtained results it was established that bulls-sires and several paragenetic factors caused no significant variation of fertility traits in relation to general average $(\mathrm{P}<0.01)$. Quantitative milk traits of first calving cows, under the influence of breeding region, had significantly higher deviation from the general average $(* *$ $\mathrm{P}<0.01$ ). Significant deviations $(* \mathrm{P}<0.05)$ were caused by year of calving on milk yield and yield of milk fat $(4765.0 \mathrm{~kg}$ and milk fat $3.86 \%)$. Established heritability coefficients for reproductive traits were following: .102, .051 and .088, and milk traits .297, .207 and .197).

Key words: Simmental, reproduction traits, heritability, cow, first calving, milk yield

\section{Introduction}

The largest cattle population in Republic of Serbia is population of Simmental cattle (approx. 500.000 female breeding animals or over $80 \%$ ). Cows of Simmental breed are reared in Republic of Serbia in semi-intensive conditions of 
housing, care and nutrition, i.e. on small farms with several heads of cattle, to farms with several tenths of female breeding animals in intensive system of housing, care and nutrition. Current programs all over the world which relate to same problem and which is target objective in our country, is increase of production performance of cattle in Serbia, which is now structurally different from situation ten or twenty years ago. If we consider current changes in regard to genetic improvement of cattle and huge progress in technologies of reproduction, it is obvious that present programs will have to be changed and improved. Since economical importance of reproduction and milk traits is high, knowledge of certain factors which influence the fertility and milk performance of cows, and are divided into genetic and para-genetic factors, is necessary. Success in improvement of fertility by genetic way is limited with low heritability values, which doesn't mean that genes have no effect on these traits, but that value of additive genetic variation is low. Heritability, i.e. study of additive genetic variance in total phenotypic variability of quantitative traits, represents the part of the most important researches from the aspect of creation of population of cattle of high genetic potentials and selection of parent couples for future generations. Values of the heritability coefficients for fertility traits are under the influence of different factors, such as: genotype, age, intensity of selection, breeding method, environment conditions, etc.

Objective of this research was to investigate heritability of fertility and milk performance traits for the purpose of selection of direction and further improvement of this population. Similar research was carried out also by Kapš and Špehar (2004), Panić and Vidović (2006), Pantelić et al. (2008), Petrović et al. (2006), Petrović et al. (1998, 1999, 2001,2006, 2007) and Ulek and Tekun (2006).

\section{Materials and Methods}

Collected data used in analysis originate from four regions - breeding regions in Serbia. Research included 3980 first calving cows of Simmental breed daughters of 32 sires, calved in the six year period (2002-2007).

Breeding regions were: Šumadija (1), Pomoravlje (2), Rasina (3) and Braničevo (4). I season of calving included months of February, march and April, II season May, June and July, III season included months of August, September and October, and IV season November, December and January. Bulls - sires are also Simmental and are in exploitation by two Livestock-Veterinary Centres in Republic of Serbia.

All investigated cattle (cows) were housed tied and free on farms of private, individual producers (of 8 to 65 heads per farm) and were fed standard diets, differences were in quantity, ratio and quality of forage and concentrated feeds (breeding region). 
Investigation of heritability of fertility and milk performance included following traits:

\section{Reproductive and Productive traits:}

- Age at first fertilisation, days (AF)

- Duration of pregnancy, days (DP)

- Duration of service period, days ( DSP)

- Milk yield 305 days (MY305D)

- Milk fat yield 305 days (MFY305D)

- Percent of milk fat 305 days (\%MF305D)

Mathematical-statistical data analysis was done using mixed model of least squares with fixed and random effects (LS-Least Squares), applying the program of least squares (LSMLMW), Harvey, 1990. In analysis of effect of breeding region, year and season of calving, bulls-sires on fertility and milk performance phenotypes of cows in the first lactation the following model was used:

$\mathrm{Y}_{\mathrm{ijklm}}=\mu+\mathrm{R}_{\mathrm{i}}+\mathrm{Y}_{\mathrm{j}}+\mathrm{S}_{\mathrm{k}}+\mathrm{B}_{1}+\mathrm{b}_{1}\left(\mathrm{x}_{1}-\mathrm{x}_{1}\right) \mathrm{e}_{\mathrm{ijklm}}$

where:

$\mathrm{Y}_{\mathrm{ijklm}}$ - individual animal $\mathbf{m}$, deriving from sire $\mathbf{i}$, reared in $\mathbf{j}$ region, calved in $\mathbf{k}$ year, $\mathbf{l}$ season

$\mu-$ general population average

$\mathrm{R}_{\mathrm{i}}$ - fixed effect (region) of breeding region (1-4)

$\mathrm{Y}_{\mathrm{j}}$ - fixed effect of year of calving (1-6)

$\mathrm{S}_{\mathrm{k}}-$ fixed effect of season of calving (1-4)

$\mathrm{B}_{1}-$ random effect of bull-sire (1-32)

$\mathrm{b}_{1}-$ linear regression effect of age at calving

$\mathrm{e}_{\mathrm{ijklm}}-$ other non-determined effects

\section{Results and Discussion}

Different number of individual animals in certain classes, as well as presence of multiple effects (region, year of calving, season of calving, bulls-sires) which influenced expressions of investigated traits, induced analysis where method of least squares was used.

Bulls-sires and series of para-genetic influences caused no significant variation of fertility traits in relation to general average $(\mathrm{P}>0.001)$. Similar data on variation of fertility traits were obtained by Petrović et al. $(2001,2007)$ and Petrović et al. (2006). 
Table 1. Mean values (LSM) and mean values standard errors (S.E.) for the reproductive traits

\begin{tabular}{|l|c|c|c|}
\hline & AF & DP & DSP \\
\hline$L S M$ & 501.8 & 282.8 & 101.3 \\
\hline$S . E$. & 1.9 & .1 & 2.9 \\
\hline
\end{tabular}

Phenotypes of milk yield and yield of milk fat obtained in our research were higher compared to results for the same breed determined by Kapš and Špehar (2004) in Croatian population of Simmental cows, and Panić and Vidović (2006), Petrović et al. (2006), and significantly higher compared to results obtained by Pantelić et al. (2008).

Quantitative milk traits of first calving cows under the influence of region had highly significant deviation from general average $(* * \mathrm{P}<0.01)$. Significant deviations $\left({ }^{*} \mathrm{P}<0.05\right)$ were caused by calving year on yield of milk and milk fat. Season of the beginning of lactation in cows included in our research showed significant deviations of milk yield and yield of milk fat from the general average $(\mathrm{P}<0.01)$. So, heifers calved in February, March and April had significantly more milk and milk fat in comparison to those which calved in other months of the year.

Table 2. Mean values (LSM) and mean values standard errors (S.E.) for the milkability traits

\begin{tabular}{|l|c|c|c|}
\hline & MY305D PM305D & MFY305D PMM305D & \%MF305D \%MM305D \\
\hline LSM & 4765.0 & 183.9 & 3.86 \\
\hline S.E. & 173.7 & 8.4 & .05 \\
\hline
\end{tabular}

Coefficients obtained in study of additive genetic in total phenotypic variability, i.e. parameters of heritability of fertility and milk traits, are presented in Table 3. Established heritability coefficients of reproduction traits obtained in our research had low values and were bellow level compared to those obtained by Petrović et al. (1998, 2001, 2006).

Table 3. Heritability $\left(h^{2}\right)$ and heritability errors (S.E. $\left.h^{2}\right)$ of reproduction and milk traits

\begin{tabular}{|l|c|c|}
\hline Trait & $\mathrm{h}^{2}$ & S.E. $\left(\mathrm{h}^{2}\right)$ \\
\hline AF & .102 & .077 \\
\hline DP & .051 & .013 \\
\hline DSP & .088 & .038 \\
\hline MY305D & .297 & .083 \\
\hline MFY305D & .207 & .061 \\
\hline \%MF305D & .197 & .089 \\
\hline
\end{tabular}


Results of heritability of milk traits obtained in our research were higher compared to coefficients for the same traits published by Panić and Vidović (2006), lower compared to research results of Petrović et al. (1999) and Kapš and Špehar (2004) and in accordance with heritability coefficients determined in Turkish population of Simmental cows by Ulek and Tekun (2006).

\section{Conclusion}

In this paper, results of the effect of direct and indirect selection of quantitative fertility and milk traits are presented, as well as share of additive genetic in total phenotypic variability (heritability) of first calving cows of Simmental breed in Serbia. Analysis included four regions - breeding regions in Serbia. Investigation included 3980 first calving cows of Simmental breed, daughters of 32 bulls-sires, calved in the six year period (2002-2007). Results of the analysis were obtained using mathematical-statistical data analysis, mixed models (Harvey, 1990). Mathematical-statistical data analysis was done using linear methods, method of least squares (LS method).

Based on obtained results it was established that bulls-sires and series of para-genetic effects caused no significant variation of fertility traits compared to general average $(\mathrm{P}>0.01)$. Quantitative milk traits of first calving cows under the influence of breeding region had highly significant deviation from general average $(* * \mathrm{P}<0.01)$. Significant deviations $(* \mathrm{P}<0.05)$ were caused by calving year on yield of milk and milk fat (4765.0 $\mathrm{kg}$ and $3.86 \%$ of milk fat). Established heritability coefficients for reproductive traits were $.102, .051$ and .088 and of milk traits .297 , .207 and .197).

\section{Acknowledgment}

Study was financed by the Ministry of Science and Technological Development of Republic of Serbia, within the project 20042-TR.

\section{Ispitivanje naslednosti fenotipova plodnosti i mlečnosti simentalske rase goveda u Srbiji}

M. M. Petrović, Lj. Sretenović, S. Aleksić, V. Pantelić, Ž. Novaković, P. Perišić, M. D. Petrović

\section{Rezime}

Najbrojnija populacija goveda u Republici Srbiji pripada Simentalskoj rasi (oko 500.000 plotkinja ili više od $80 \%$ ). Ako se imaju u vidu tekuće promene u 
genetskom poboljšanju goveda $\mathrm{i}$ veoma velikom napretku $\mathrm{u}$ tehnologijama reprodukcije, očigledno da će se sadašnji programi morati menjati i poboljšavati. S obzirom na to, da je ekonomski značaj reproduktivnih i osobina mlečnosti visok neophodno je poznavanje pojedinih faktora koji utiču na plodnost i mlečnost krava, a oni se dele na genetske i paragenetske. Uspeh u poboljšanju plodnosti genetskim putem je dosta ograničen niskim vrednostima heritabiliteta, što ne znači da geni ne deluju na ovu osobinu, već da je vrednost aditivne genetske varijacije mala. Naslednost, odnosno proučavanje aditivne genetske varijanse $u$ ukupnoj fenotipskoj varijabilnosti kvantitativnih osobina, predstavlja deo najvažjnijih istraživanja sa gledišta stvaranja populacije goveda visokih genetskih potencijala i odabiranja roditeljskih parova budućih generacija. Vrednosti koeficijenata naslednosti za osobine plodnosti su pod uticajem različitih faktora, kao što su: genotip životinje, uzrast, intenzitet selekcije, metod odgajivanja, ambijentalni uslovi i dr.

Cilj ovih istraživanja je bio da se ispitaju važniji genetski parametri plodnosti i mlečnosti, odnosno naslednosti ovih kvantitativnih osobina radi izbora pravca i daljeg oplemenjivanja ove populacije.

Prikupljeni podaci za analizu potiču iz četiri regiona - odgajivačka područja u Srbiji. Istraživanja su uključila 3980 krava - prvotelki simentalske rase, kćeri 32 bika - oca, koje su oteljene u periodu od šest godina (2002-2007). Sva ispitivana grla (krave - prvotelke) su držana vezano i slobodno u posedu privatnih farmera (od 8 do 65 grla po farmi) i bila su standardno hranjena, a razlike su bile u količini, odnosu i kvalitetu kabaste i koncentrovane hrane (područje gajenja).

Matematičko-statistička analiza podataka obavljena je primenom mešovitog modela najmanjih kvadrata (LS-Least Squares) primenom programa najmanjih kvadrata (LSMLMW), Harvey, (1990). Različiti broj individua u pojedinim klasama kao i postojanje više uticaja (područje, godina telenja, sezona telenja, bikovi očevi) koji su delovali na ispoljavanje ispitivanih osobina, uslovio je analizu u kojoj je korišćen metod najmanjih kvadrata. Bikovi-očevi i niz paragenetskih uticaja nisu prouzrokovali značajno variranje osobina plodnosti u odnosu na opšti prosek $(\mathrm{P}<0.01)$.

Kvantitativne osobine mlečnosti krava prvotelki su pod uticajem odgajivačkog područja imale visoko značajno odstupanje od opšteg proseka (** $\mathrm{P}<0.01)$. Značajna odstupanja $(\mathrm{P}<0.05)$ je izazvala godina telenja na prinos mleka $\mathrm{i}$ mlečne masti. Godišnje doba početka laktacije krava obuhvaćenih našim istraživanjem pokazuje značajna odstupanja prinosa mleka i mlečne masti u odnosu na opšti prosek $(\mathrm{P}<0.01)$. Tako su junice oteljene u februaru, martu i aprilu imale značajno i visoko značajno više mleka i mlečne masti u odnosu na one koje su se otelile u drugim mesecima u godini.

Ustanovljeni koeficijenti heritabiliteta reproduktivnih svojstava koji su dobijeni našim istraživanjem su imali niske vrednosti i bili su nižeg nivoa u odnosu na one koje su dobili Petrović et al. (1998, 2001, 2006). Rezultati naslednosti 
osobina mlečnosti dobijeni našim istraživanjima su bili viši u odnosu na koeficijente za iste osobine koje su objavili Panić and Vidović (2006), niži u odnosu na rezultate istraživanja Petrović et al. (1999) and Kapš and Špehar (2004) a u saglasnosti sa koeficijentima heritabiliteta koje su u turskoj populaciji simentalskih goveda ustanovili Ulek and Tekun (2006).

\section{References}

KAPŠ M., ŠPEHAR M. (2004): Estimation of Genetic Parameters and Breeding Values of Milk Traits for Simmental Cattle in Croatia Using a Lactation Animal Model. Agric. Conspec. Sci., 69, 4, 91-94.

HARWEY W.R.(1990): Mixed Model Least Squares and Maximum Likelihood Computer Program. User, s Gguide for LSML MW and MIXMDL.

PANIC J., VIDOVIĆ V.(2006): Heritabilnost važnijih svojstava mlečnosti krava simentalske rase. Biotehnology in Animal Husbandry, 22, 1-2, 55-64.

PANTELIĆ V., PETROVIĆ M.M., ALEKSIĆ S., SRETENOVIĆ LJ., OSTOJIĆANDRIĆ, D., NOVAKOVIĆ Ž. (2008): Investigation of the Genetic Correlation Between Milk and Fertility Traits of First Calving Cows of Simmental Breed. Biotechnology in Animal Husbandry, 24, 5-6,1-8.

PETROVIĆ M.D., ĐOKOVIĆ R., BOGOSAVLJEVIĆ-BOŠKOVIĆ S., KURČUBIĆ V. (2006): Uticaj paragenetskih faktora na proizvodne osobine standardnih laktacija kod krava simentalske rase. Savremena poljoprivreda, 55, 12, 138-143.

PETROVIĆ M.M., LAZAREVIĆ R., LAZAREVIĆ R., ALEKSIĆ, S., MIŠČEVIĆ, B.NIKITOVIĆ N. (1998): Heritability and Correlation of Reproductive and Milkability traits of Black and White Cattle. Biotechnology in Animal Husbandry, 14, 1-2, 15-20.

PETROVIĆ M.M., LAZAREVIĆ R., ALEKSIĆ S., MIŠČEVIĆ B. PERKOVIĆ S., ILIĆ Z. (1999): Comparative Investigation of The Heritability of Milkiness Phenotypes in the Daughters of Simmental and Holstein-Friesian Bull-sires in Serbia. Biotechnology in Animal Husbandry, 15, 5-6, 125-132.

PETROVIĆ M.M., LAZAREVIĆ R., ALEKSIĆ S., MIŠČEVIĆ B. (2001): Heritability and Reproductive Traits of Different Genotypes of Black and White Cattle. Biotehnology in Animal Husbandry, 17, 1-2, 3-10.

PETROVIĆ M.M., SMILJAKOVIĆ T., PANTELIĆ, V., SRETENOVIĆ LJ., OSTOJIĆ-ANDRIĆ D. (2006): Results of the Application of Technologicalgenetic Procedures in Reproduction of Cattle with them to Improve the Milk Production. The $35^{\text {th }}$ International Session of Scientific Communications the Scientific papers of the Faculty of Animal Science, Bucharest 2006, Romania, 219224. 
PETROVIĆ M.M., SRETENOVIĆ LJ., PANTELIĆ V., ALEKSIĆ S., MIŠČEVIĆ B., BOGDANOVIĆ V., OSTOJIĆ-ANDRIĆ D., PETROVIĆ M. (2006): Results of the Application of the Technology of Genetic Improvement of Simmental Cattle Population in Serbia. Biotechnology in Animal Husbandry, 22, 1-2, 1-8.

ULEK S., TEKUN M.E. (2006): Calculation of Adjustment Factors for Standardizing Lactations to Mature Age and 305-Day and Estimation of Heritability and Repeatability of Standardized Milk Yield of Simmental Cattle Reared on Kazova State Farm. Turk. J. Vet. Anim. Sci., 30, 293-289.

Received 31 May 2009; accepted for publication 15 August 2009 